recent example is the Southern Gas Board's new installation of continuous catalytic conversion plant at Hythe, Hampshire. This is next door to the Esso Petroleum Company's refinery at Fawley. ". . . when it is commis. sioned early in 1964 it will, in fact, draw all the materials necessary to produce about 35 million cubic feet of gas a day from the refinery. Using the I.C.I. type of plant it will steam-reform naphtha and enrich it with refinery gas. Each year the Hythe works will take about 60,000 tons of naphtha and 23 million therms of refinery gas."

Substantial quantities of naphthe and liquefied petroleum gases are being supplied for the same purpose to other Gas Boards in Britain. In the case of the Scottish Gas Board's new works at Provan, Glasgow, the plant when fully in commission will have a capacity of about 50 million cubic feet of gas per day, involving supplies of more than 100,000 tons of naphtha and 80,000 tons of liquefied petroleum gases a year.

Thus until comparatively recently the oil industry supplied less than one-tenth of the feed-stock required for the production of town gas. To-day it supplies more than one-quarter of the raw material necessary. It is calculated that by 1967 the petroleum industry will be responsible for more than half the raw materials needed for Britain's entire gas supply. It may even be more if natural gas is included, for example, from the Sahara. Should success attend present explorations of the North Sea bed for oil or natural gas or both, especially within British territorial waters, then looking ahead to, say, 1975 , ". . . it seems highly probable that, together, oil and natural gas will be indirectly supplying about ninetenths of the nation's town gas". H. B. Mruner

\title{
THE TWO BIOLOGIES
}

I his inaugural lecture before the University of Oxford I On October 24, 1963, now published under the title The Two Biologies*, Prof. J. W. S. Pringle distinguishes between the consideration of how organisms came to be what they are and what functions their parts have in relation to the whole, and the analysis of what existing organisms are and how what they and their parts do can be described in terms of chemistry and physics. These are his two biologies, and while he thinks much of the present excitement derives from the promise which the second, analytical biology, is thought to hold for a fuller understanding of the nature of life, he examines the relation of biology to the rest of natural science and its present status in the intellectual endeavour of mankind. $\mathrm{He}$ argues that we have now to consider not only the philosophy of biology, but also the biology of philosophy. We are approaching the point when it is possible to investigate the types of thought process which go on in the human mind and determine the way in which we think and reason. $\mathrm{He}$ suggests that it is only by accepting a relativistic philoso-

The Two Biologies. (An Inaugural Lecture delivered before the University of Oxford on 24 October, 1963.) Pp. 28. By Prof. J. W. S. Pringle. (Oxford: Clarendon Press; London: Oxford University Press, 1963.) 3s. 6d. net. phy, in which man surrenders the vantage point from which he has claimed to be able to look out on the world, that he will achieve real consistency.

Prof. Pringle does not suggest that the new era in biology is to be identified as a replacement of the evolutionary biology by the new molecular biology: they are complementary within a host of branches of biology. This he illustrates by examples of the procedure of both biologies. After stressing that the dynamic equilibria in biology are not identical with the dynamical equilibria of statistical mechanics, he points out that organization of living organisms can preserve a fixed hierarchy. Hence the dynamically stable systems at one level survive to form the units which generate the next level, and so a progressive development can occur over a long period. This fixation depends on the existence of a particular type of chemical molecule in the cell-desoxyribonucleic acid. In the study of animal behaviour there has also to be a hierarchy of explanation, and from this he goes on to argue that biology must be extended to include the study of understanding and explanation. From this philosophical point of view he finds that biology provides both a magnificent framework for intellectual endeavour and a most satisfying way of life.

\section{STRONTIUM-90 AND C/ESIUM-I37 IN MILK AT ISPRA, ITALY, DURING 1960-62}

\author{
By M. De BORTOLI, P. GAGLIONE, Dr. A. MALVICINI and E. VAN Der STRICHT \\ Service de Protection, Section Site et Météorologie, C.C.R., Euratom, Ispra, Italy
}

\begin{abstract}
CINOE January 1960 routine analyses of the radio$S$ activity of samples of milk have been included in the programme of the environmental monitoring group of the Euratom Nuclear Research Centre at Ispra, Italy. Samples are taken monthly from four local dairies; in addition, regular checks are made of milk produced in an extensive zone of irrigated pastures east of Milano and sold in this city.
\end{abstract}

All samples are controlled for $\gamma$-activity with a multichannel $\gamma$-spectrometer and analysed for radiostrontium.

We shall limit ourselves in this article to report the results obtained and to make some comments with regard to the so-called 'observed ratio' (S.U. milk/S.U. diet), the ratio S.U./K.U. (that is, $\frac{\text { pc. }{ }^{90} \mathrm{Sr} / \mathrm{g} \mathrm{Ca}}{\mathrm{pe} .{ }^{137} \mathrm{Cs} / \mathrm{g} \mathrm{K}}$ ) and the relative contributions of the direct and indirect contamination of grass to the radioactivity of milk by means of the ${ }^{89} \mathrm{Sr}$ ${ }^{90} \mathrm{Sr}$ ratio. Details concerning the methods of analysis and of measurement are described in Euratom Report EUR $294 i$ together with the complete set of experimental results.

Figs. 1 and 2 show the fluctuations of the radioactivity due to strontium-90 and cæsium-137 in milk both for the Milano zone and the villages surrounding the Centre. Results are given as pe. ${ }^{90} \mathrm{Sr} / \mathrm{g} \mathrm{Ca}$ and pc. ${ }^{137} \mathrm{Cs} / \mathrm{g} \mathrm{K}$.

It is at once evident that, although the trend is quite similar, the activity in the immediate vicinity of the Centre is more than twice that of the Milano area. The reason for this should be sought in the difference in geographical and meteorological conditions between the two areas. Precipitation is nearly double at Ispra $(1,900 \mathrm{~mm} /$ year against $900 \mathrm{~mm} /$ year) and the pastures of the area have a low productivity. 